\title{
HISTOPATHOLOGY OF SUBCUTANEOUS TISSUE REACTION TO ENDODONTIC ROOT
} CANAL SEALERS

\author{
VUJAŠKOVIĆ MIRJANA*, KARADŽIĆ B* and BACETIĆ D** \\ *University of Belgrade, Faculty of Dentistry, Serbia \\ **Institute of Pathology ,Faculty of Medicine, University of Belgrade, Serbia \\ (Received $17^{\text {th }}$ November 2010)
}

The aim of the study was to evaluate tissue response of two root canal sealers: Endomethasone (cink oxide eugenol-based sealers) and Ketac Endo Aplicap (glass ionomer based sealers). The sealers were freshly mixed and injected into subcutaneous connective tissue of the dorsal surface of experimental animals (Wistar Furth rats). The inflammatory reaction caused by the sealers was evaluated 7, 30 and 60 days after implantation using descriptive hisopathological analysis. The tissue sections were taken from injection sites. Each incision included skin,subcutaneous connective tissue and underlying muscular tissue. All blocks were proceeded using standard histological procedures. The tissue reactions were graded as mild,moderate or severe inflammation.

After the seven days both sealers showed a moderate reaction with a decreasing trend. Both materials caused mild inflammation which diminished at the end of the experimental period.

The results of this study demonstrate that Ketac Endo and Endomethasone is well tolerated by subcutaneus connective tissue of experimental animals.

Key words: biocompatibility, connective tissue, root canal sealers

\section{INTRODUCTION}

Teeth with severe pulpal or periapical inflammation can be sucessifully treated with the established techniques of cleaning and shaping the root canals followed by obturation of the root canal system.

Materials for obturation that are used consist of gutta-percha and paste or cement. Root canal sealers are based on various formulas such as zinc oxide eugenol, epoxy resin, calcium hydroxide and glass ionomer cement.

Ideally, root canal sealers should be biocompatible and have satisfactory physico-chemical properties. They should also be well tolerated by the periradicular tissue.

Their biocompatibility is of primary importance because these materials will be in direct contact with periapical tissue for prolonged time and might affect the 
periapical tissue, if extruded. In such a condition they could cause degeneration of the tissue and could also delay wound healing (Geurteson, 2001; Kim et al., 2004; Eldeniz et al., 2007).

Previous studies have shown that the biocompatiblity of different types or products of root canal sealers varies considerably (Kolukoris et al., 1998; Schwarze et al., 2002). Most products exert some toxic effect, when they are fresh, with the effect reduced over time as the concentration of components decreases.

The zinc-oxide and eugenol based sealers (ZOE) are the most popular and have been used extensively for many decades (Pommel et al., 2003). Endomethasone (Setododont, France) is a ZOE-based sealer that was previously assessed in various studies regarding its biological properties (Zafalon et al., 2007).

The glass ionomer cements (GIC) were developed by Wilson and Kent, bonding chemically to the inorganic phase of enamel and dentin whilist realasing fluoride ions.

Pitt Ford (1979) first suggested the use of glass ionomer cement (GIC) as a root canal filling. GIC posses certain properties as an obturation material. Firstly, its has the ability to chemically and micromechanically adhere to root dentin and may improve the resistence to root fracture. Secondly, when used as a sealer in conjuction with condensed gutta-percha in vivo, it may resist microbial ingress better than zinc oxide eugenol-based sealer (Friedman et al., 2000). Thirdly, it exerts antimicrobial activity resulting from fluoride release, low $\mathrm{pH}$ levels when setting and presence of components such as stroncium and zinc (Herrera et al., 2001). However, Schalhav et al. (1997) concluded that because of a rapid decrease in fluoride release after mixing, the antibacterial activity of Ketac Endo (GIC for root canal filling) also significantly diminishes (within 24 hours from mixing).

Glass ionomer cements are used in endodontics for sealing and restoring the pulp chamber and for repairing perforations and retrograde filling. They are also used for their capacity to bond to dentin, and their good biocompatibility. The main function is to enhance the seal and reinforce the tooth, than to minimise the irritation of the periradicular tissues and antimicrobial effect against root canal infection.

Many different methods have been described for assesing tissue toxicity. One of the most practical and widely used methods is the implantation of the material into the subcutaneous tissue. The irritant effect of endodontic materials is evaluated by the histopathological examination of the tissue response around the material.

The purpose of this study was to evaluate the reaction of subcutaneous connective tissue to ZOE-based sealer Endomethasone and glass ionomer cement (Ketac Endo Aplicap).

\section{MATERIALS AND METHODS}

Materials: Two root canal sealers and a control material were evaluated: Endomethasone, Ketac Endo Aplicap and rose wax as control materials. The 
Acta Veterinaria (Beograd), Vol. 61, No. 2-3, 327-336, 2011.

Vujašković Mirjana et al.: Histopathology of subcutaneous

tissue reaction to endodontic root canal sealers

materials tested were zinc-oxide and eugenol based and glass ionomer based (Table 1).

Table 1. Composition of the investigated materials

\begin{tabular}{|l|l|l|}
\hline Manufacuturer & Component A & Component B \\
\hline \hline \multirow{4}{*}{$\begin{array}{l}\text { Endomethasone } \\
\text { (Septodonte,France) }\end{array}$} & Zinc oxide (49\%) & Eugenol (91\%) \\
\cline { 2 - 3 } & Thymol iodine (25\%) & Pepermint oil (9\%) \\
\cline { 2 - 3 } & Barium sulfat (15\%) & \\
\cline { 2 - 3 } & Hydrocortisone acetate (1\%) & \\
\cline { 2 - 3 } & Dexamethasone paraformaldehyde & \\
\hline $\begin{array}{l}\text { Ketac Endo Aplicap } \\
\text { (Espe,Seefeld,Germany) }\end{array}$ & Calzium-Lanthane-Sodium & Polyacrilic acid \\
\cline { 2 - 3 } & Fluorophosphor-Aluminium-Silicate & Wine acid \\
\hline
\end{tabular}

Method: Twelve white female Wistar-Furth rats, weighing between 150 to $200 \mathrm{~g}$ were used in this study. The animals were anesthesed intraperitoneally with $0.2 \mathrm{~mL}$ ketamine.

After shaving the animals' back and desinfection with alcohol and iodine tincture, four operative areas were marked, two from the left and two from the right side (two for test sealers and two for control material). Small incisions were made in the dorsum with a blade. The sealers were freshly mixed and injected in the dorsal subcutaneous connective tissue. The animals were killed in groups of 4 after 7,30 and 60 days.

Tissue sections were taken from selected sites. Each section included the skin, subcutaneous connective tissue and underlying muscule tissue. All blocks were immersed in $10 \%$ solution of formalin. After fixing tissue for $48 \mathrm{~h}$ it was processed for parafin embedding. Parafin blocks were cut in serial sections with the microtome set. Section were stained with hematoxylin and eosin.

The state of the surrounding tissue, the occurance and location of fibrous tissue, as well as various types of inflammatory cells were examined. Tissue reactions were graded as mild, moderate and severe, according to criteria suggested by Orstavik and Mjor (1988).

\section{RESULTS}

The intensity of the inflammatory response in all experimental periods of both sealers were analyzed.

Ketac Endo

Moderate to severe inflammatory reaction with necrosis was observed with Ketac Endo on the 7th day. The tissue was infiltrated with neutrophils (Fig 1). The intensity of reaction diminished on the 30 th day. It was characterized by the presence of macrophages, giant cells with engulfed material in their cytoplasm (Fig 2). The connective tissue was infiltrated by plasma cells and macrophages 
but few polimophonuclear leucocytes (Fig 3). Reduction continued progressively to the 60th day with mild inflammation and signs of reparation (Fig 4).

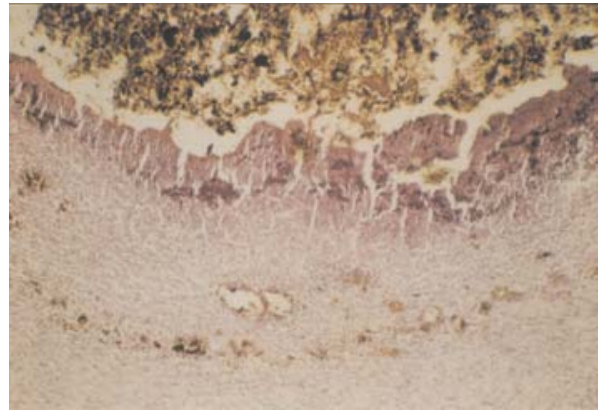

Figure 1. Ketac-Endo 7th day; The moderate to severe inflammation with necrosis reaction (HE X 63)

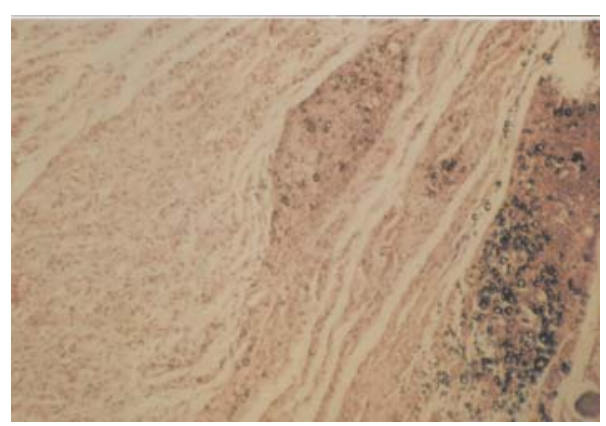

Figure 3. Ketac-Endo 60th day; Proliferation of fibrous tissue with chronic inflammation (HE X 100)

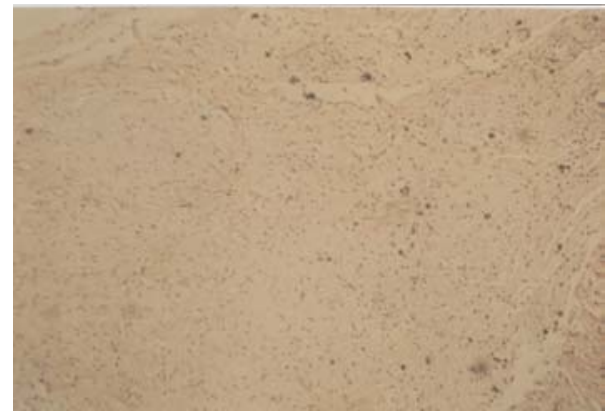

Figure 2. Ketac-Endo 30th day; Presence of inflammatory infiltrate with macrophages, lymphocytes and polymorphonuclear cells (HE X100)

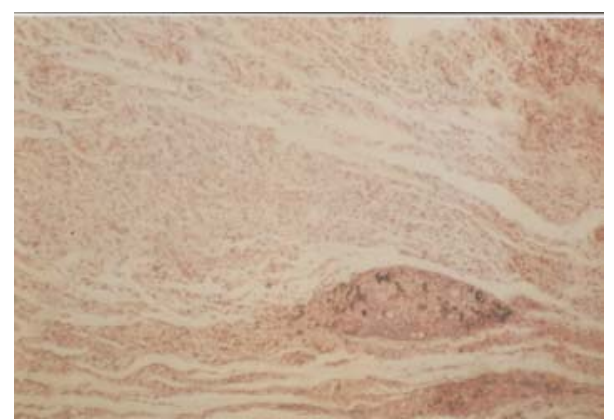

Figure 4. Presence of connective tissue with the rests of material (HE X 80)

\section{Endomethasone}

Severe inflammation with necrosis and presence of polymorphonuclear leucocytes was observed in the Endomethasone speciemen on the 7th day (Fig 5).The intensity of reaction diminished at the 30th day of inspection. It was characterised by the granulomatous tissue with well formed fibrous capsulechronic abscess (Fig 6,7). On the 60 th day, giant cells with engulfed particles of the material were seen (Fig 8) along with a presence of connective tissue. 


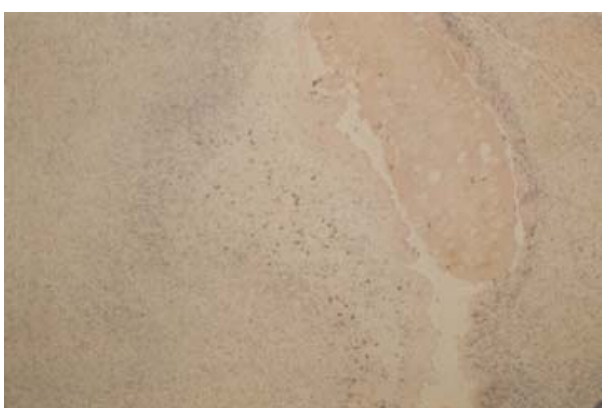

Figure 5. Severe inflammatory reaction 7 days after Endomethasone implantation. Presence of inflammatory infiltrate with polymorphonuclear cells and macrophages (HE X 63)

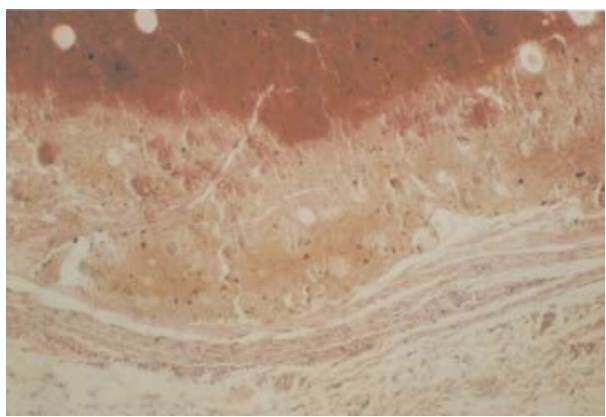

Figure 7. Endomethasone at 30 th days; The connective tissue was infiltrated by lymfocytes, plasma cells and macrophages (HE X 80)

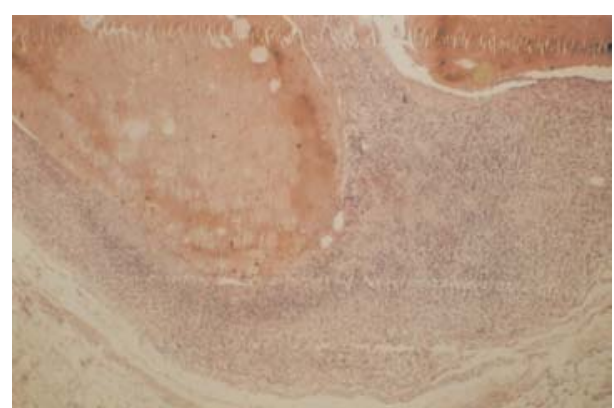

Figure 6. Inflammatory reaction surrounded particules of material with granulamatous tissue (chronic abscess) (HEX63)

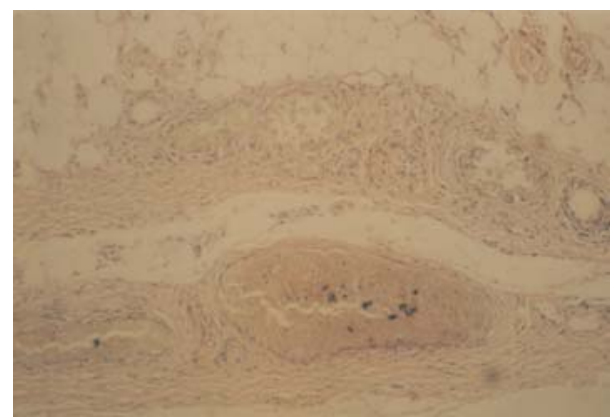

Figure 8. Endomethasone at 60 th day; Presence of macrophages with engulfed particles of material and well formed fibrous tissue capsule (HE X 240)

\section{DISCUSSION}

The biocompatibility of dental materials is an important requirement since the toxic components present in these materials could produce irritation or even degeneration of the surrounding tissues,especially when accidentally extruded into the periradiculare tissues (Hummonen et al., 2003).

Various in vitro tests have been used to evaluate the irritant properties of endodontic sealers. One of the methods for testing biological compatibility of root canal sealers is to use an in vitro model to determine the cellular response (Cohen et al., 2000; Leonardo et al., 2000). However, in vivo tests are based on clinical and hystological appraisals of tissue responses and probably correlate better than in vitro (Brett et al., 2000; Figuierdo et al., 2001; Shuang et al., 2002; Camps, 2003). 
The subcutaneous connective tissue implantation in animals is one of the most realable methods of evaluating biocompatibility of dental materials (Oney et al., 2007; De Campos et al., 2008) because inflammmatory reactions are characteristic features for all connective tissues (Vujašković and Bacetić, 2004).

In this study, the early tissue responses of both materials have shown more than moderate inflammation because the tested root canal sealers have a high initial toxicity before setting (Vujašković, 1999; Kim et al., 2004). However, the inflammatory reactions of the sealers decreases with time. At the end of the experimental period (after 60 days), tissue response was significantly lower than the one at one week and developement of well formed fibrous capsule was observed.

In the present study the connective tissue on control materials did not present inflammatory reactions.

The result of the present study study demonstrate that glass ionomer Ketac Endo is well tolerated by the tissue similar to the results obtained by Kolokuris et al. (1998). The inflammatory reaction of Ketac Endo was moderate after 7 days and mild after four weeks, but at the end of the observation period it has diminished. According to Kolokuris et al., 1998. biocompatibility of the glass ionomer sealer in subcutaneous connective tissue, Ketac Endo was biocompatible with only minor irritation after 120 days.

An in vivo study over 270 days with Ketac Endo fillings in root of dog teeth revealed a satisfactory biocompatibility in the apical area (Leonardo et al., 1998).

Thom et al. (2003) have reported that GIC Ketac Endo was the most cytotoxic when mixed fresh. It has been attributed to a several possible factors, including the silica, aluminium, calcium, phosphate and fluoride ions released from the glass particles. The polyacid component could also create a decreased $\mathrm{pH}$. The glass ionomer cement has low chemical stability and thus should be isolated from liquid media for the first $24 \mathrm{~h}$ because of their setting reaction, and early exposure and that may favour desintegration (Schwarze et al., 2002; Kaplan et al., 2003).

Beltes et al. (2003) have reported mild cytotoxicity when Ketac Endo was allowed to set for 6 hours and than left in contact with a fibroblast cell line in vitro for periods of 1, 2 and 3 days. Jonck et al. (1989) demonstrated exellent bone tollerance of experimental glass-ionomer cements, including a root canal sealer and bone cement used in ortopedic surgery.

Endomethasone, zinc oxide-eugenol based sealers consist of paraformaldehyde and antiinflammatory steroids (corticosteroids). This is the most popular root canal sealer which practicioners use in our area. The opinions about this material are contaversal.

Previous reports have shown that Endomethasone reacts in a cytotoxic manner and is irritative on the periradicular tissue (Mittal et al., 1995; Leonardo et al., 1999). Many investigators have suggested that the irritative ability of ZOEbased sealers could be attributed primarily to eugenol and secondarily to zinc ions (Leonardo et al.1999; Leonardo et al., 2000; Huang et al., 2002; Camps et al., 2003). Eugenol can inhibit the macrophage function and any influence of the inflammatory reaction in the periapical tissues (Hummonen et al., 2003). 
Paraformaldehyde provoked an allergic reaction and necrosis of the connective tissue. Several studies reported that the combined effects of eugenol and formaldehyde might explain why Endomethasone was highly toxic, with strong and irreversible toxic effect on the nerve tissue (Brodin et al., 1982; Leonardo et al., 1999; Brenath et al., 2003).

Mainly, endodontic sealers based on zinc oxide-eugenol exibited severe cytotoxic effects or implantation test, especially N2 paste, but Endomethasone may slowly desintegrate in root canals after a 10 week period of wet storage, which than may have caused a delayed liberation of cytotoxic component, such as eugenol or thymol (Schwarze et al., 2002).

ZOE sealers containing paraformaldehyde were highly toxic. The cytotoxic, mutagenic and cancerogenic potential of formaldehyde, as well as its systemic effect have been demonstrated in vitro and in vivo (Huang et al., 2002; Yaltirik et al., 2002).

However, in the present study such findings were not observed. It provoked moderate to severe inflammatory reaction which decreased during the experimental period. Similar to the results obtained by Batista et al. (2006), Kaplan et al. (2003), Zafalon et al. (2007), the subcutaneous tissue inflammatory reaction was mild after 30th day and decreased after 60th day, probably owing to the neutralization of the free eugenol at the start and by the local liberation of corticoids such as dexamethasone and hydrocortisone (Kaplan et al., 2003; Zafalon et al., 2007).

Bernanth and Szabo (2003) reported that Endomethasone did not cause an inflammatory reaction in six of nine obturated root canals in monkeys.

Several studies with ZOE-based obturating materials have shown that the intensity of the inflammatory response is directly related to the powder/liquid ratio used, and that the quantity of free eugenol depends on the mixture consistency during hardening. Since Endomethasone has powder/liquid proportion of 7:1, it may release less eugenol causing only a mild inflammatory response (Batista et al., 2003).

\section{CONCLUSION}

Although both materials have shown moderate inflammation as a reaction to foreign body in the beginning, the inflammation has diminished and almost completly dissapeared after the observation period. This clearly shows good biocompatibility of both root canal sealers used in this research.

Address for correspondence:

Associated professor Vujašković Mirjana

Department of Conservative and Endodontic Dentistry

Faculty of Dentistry

University of Belgrade

Rankeova 4

Belgrade, Serbia

E-mail: vujaskovic@sezampro.yu 


\section{REFERENCES}

1. Batista FCR, Hidalgo MM, Hernandes L, Consolaro A, Velloso TRG, Cuman RKN et al., 2006, Microscopis analysis of subcutaneous reactions to endodontic sealer implants in rats, $J$ of Biomed Mat Res, Part A DOI 10 1002/jbm.a,171-77.

2. Beltes $P$, Koulaouzidou E, Kolokuris I, Kortsaris $A H, 1997$, In vitro evaluation of cytotoxicity of two glass ionomer root canal sealers, J Endod, 23, 572-4.

3. Bernath M, Szabo J, 2003, Tissue reaction initiated by different sealers, Int Endod J, 36, 256-61.

4. Brett IC, Mark KP, Barry LM, Allan SD, 2000, An in vitro study of the citotoxicity of two root canal sealers, J Endod, 26, 228-9.

5. Brodin P, Read A, Aars H, Orstavik D, 1982, Neurotoxic effects of root filling materials on rat phrenic nerve in vitro, J Dent Res, 61, 1020-3.

6. Camps J, 2003, Cytotoxicity testing of endodontic sealers: A New Method, J of Endod, 29, 583-6.

7. Cohen BI, Pagnillo MK, Musikant BL, Deutsch AS, 2000, An in vitro study of the citotoxicity of two root canal sealers, $J$ Endod, 26, 228-9.

8. De Campos-Pinto MM, de Oliveira DA, Versiani MA, Silva-Souza JTC, Souza Neto MD, Cruz Peres $D E$ et al., 2008, Assesement of biocompatibility of Epiphany root canal sealer in rat subcutaneous tissue, Oral Surg Oral Med Oral Pathol Oral Radiol Endod, 105, e77-e81.

9. Eldeniz AU, Mustafa K, Orstavik D, Dahl JE, 2007, Citotoxicity of new resin, calcium hydroxide and silicone-based root canal sealers on fibroblasts derived from human gingiva and L929 cell lines, Int Endod J, 40, 329-37.

10. Figuiredo JAP, Pesce HF, Gioso MA, Figueiredo AZ, 2001, The histological effect of four endodontic sealers implanted in the oral mucosa: submucous injection versus implant in polyethilene tubes, Int Endod J, 34, 377-85.

11. Friedman S, Komorowski R, Maillet W, Klimaite R, Nguyen HQ, Torneck CD, 2000, In vivo resistance of coronally induced bacterial ingress by an experimental glass ionomer cement root canal sealer, J Endod, 26,1-5.

12. Geurteson W, 2001, Biocompatibility of root canal filling materials, Australian Endod J, 27, $12-21$.

13. Herrera $M$, Carrion $P$, Baca P, Liebana J, Castillo A, 2001, In vitro antibacterial activity of glass ionomer cements, Microbios, 104, 141-8.

14. Huang F M, Tai K W, Chou M Y, Chang YC, 2002, Cytotoxicity of resin, zinc oxide-eugenol and calcium hydroxide-based root canal sealers on human periodontal ligament cells and permanent V79 cells, Int Endod J, 35, 153-8.

15. Hummonen S, lenander-Lumikari M, Sigurdsson A, Orstavik D, 2003, Healing of apical periodontitis after endodontic tretment:a comparison between a silicone based and zinc-oxide-eugenol based sealer, Int Endod J, 36, 296-301.

16. Jonck LM, Grobbelar CJ, Strating H, 1989, The biocompatibility in joint replacement; Bulk testing, Clin mater, 4, 85-107.

17. Lalh MS, Titley K, Torneck CD, Friedman S, 1999, The shear bond of glass ionomer cement sealers to bovine dentine conditioned with common endodontic irrigants, Int Endod J, 32, 430-35.

18. Leonardo MR, Amelaida WA, da Silva LAB, Utrilla LS, 1998, Histological evaluation on the response of the apical tissue to glass ionomer and zinc oxide-eugenol based sealers in dog teeth after root canal tretment, Endod dent Traumatol, 14, 257-61.

19. Leonardo RT, Consolaro A, Carlos IZ, Leonardo MR, 2000, Evaluation of cell culture cytotoxicity of five root canal sealers, $J$ of Endod, 26, 328-30.

20. Leonardo MR, da Silva LAB, Filho MT, da Silva RS,1999, Release of formaldehid by 4 endodontic sealers, Oral Surg Oral Med Oral Pathol Oral Radiol Endod, 8, 221-5.

21. Kaplan AE, Ormaechea MF, Picca MC, Canzobre MC, Ubios AM, 2003, Rheological properties and biocompatibility of endodontic sealers, Int Endod J, 36, 527-32.

22. Kim JS, Beak SH, Bae KS, 2004, In vivo study on the biocompatibility of newly developed calcium phosphate - based root canal sealers, J Endod, 30, 708-11.

23. Kolukoris I, Beltes P, Economides N, Viemmas I, 1996, Byocompatibility of a new glass-ionomer root canal sealer (Ketac-Endo), J Endod, 22, 395-8. 
24. Kolukoris I, Economides N, Beltes P, Viemmas I, 1998, In vivo comparison of the biocompatibility of two root canals sealers implanted into subcutaneous connective tissue of rats, J Endod, 24, 825.

25. Mittal M, Chandra S, Chandra S, 1995, Comparative tissue toxicity of four endodontic sealers, J Endod, 21, 622-6.

26. Orstavic D, Mjor IA, 1988, Histoptology and x-ray microanalysis of the subcutaneous tissue response to endodontic sealers, J Endod, 14, 33-44.

27. Pitt Ford TR, 1979, The leakage of the root fillings using glass ionomer cement and other materials, Br Dent J, 146, 273-8.

28. Pommel L, About I, Pashley D,Camps J,2003, Apical leakage of four endodontic sealers, J Endod, 29, 208-10.

29. Schwarze T, Leyhausen G, Geurtsen W, 2002, Long term cytocompatibility of various endodontic sealers using a new root canal model, $J$ Endod, 28, 749-53.

30. Shalhav M, Fuss Z, Weiss El, 1997, In vitro antibacterial activity of a glass ionomer endodontic, $J$ Endod, 23, 616-9.

31. Thom DC, Davies JE, Santerre JP, Friedman S, 2003, The hemolitic and cytotoxic properties of a zeolite-containing root filling material in vitro, Oral Surg Oral Med Oral Pathol Oral Radiol Endod, 95, 101-8.

32. Vujašković $M$, Bacetić $D, 2004$, Reakcija tkiva na materijale za trajno kanalno punjenje kanala korena zuba, Serbian Dental J, 51, 136-40.

33. Vujašković $M, 1999$, Biofizičke osobine glas jonomer cementa za kanalno punjenje u poređenju sa standardnim materijalima, PhD Thesis, University of Belgrade.

34. Yaltirik M, Ozbas $H$, Erisen $R$, 2002, Surgical manegment of overfilling of the root canal: A case report, Quintenss Int, 33, 670-2.

35. Zafalon EJ, Versiani MA, de Souza CJA, Moura CCG, Dechici P, 2006, In vivo comparison of the biocompatibility of two root canal sealers implanted into the subcunaeous connective tissue of rats, Oral Surg Oral Med Oral Pathol Oral Radiol Endod, 103, e88-e 94.

\title{
REAKCIJA POTKOŽNOG VEZIVNOG TKIVA NA MATERIJALE ZA DEFINITIVNO PUNJENJE KANALA KORENA
}

\author{
VUJAŠKOVIĆ MIRJANA, KARADŽIĆ B i BACETIĆ D
}

\section{SADRŽAJ}

Cilj ovih proučavanja je bio ispitivanje biokompatibilnosti dva materijala za definitivno kanalno punjenje: Endomethasone (materijal na bazi cink oksid eugenola) i Ketac Endo Aplocap (glas jonomer cementa za kanalno punjenje). Sveže pripremljeni materijali su injicirani u potkožno vezivno tkivo leđnog dela eksperimentalnih životinja (pacovi Wistar soja). Intenzitet inflamatorne reakcije proveravan je nakon 7, 30 i 60 dana na osnovu patohistološke analize. Isečak je uzet sa mesta aplikacije materijala i obuhvatao je deo kože, potkožno tkivo i deo mišićnog sloja. Tkiva su podvrgnuta standardnoj histološkoj obradi. Reakcija tkiva na ubačeni materijal označena je kao blaga, srednja i jako izražena inflamacija.

Posle prvog perioda od 7 dana oba materijala su izazvala intenzivnu zapaljensku reakciju tkiva sa kasnijom tendencom smanjenja inflamacije. Oba materi- 
jala su izazvala umereno zapaljenje koje je nestalo do kraja eksperimentalnog perioda.

Postignuti rezultati ukazuju da su Ketac Endo i Endomethasone biokompatibilni u potkožnom vezivnom tkivu eksperimentalnih životinja. 